Boston University School of Law Scholarly Commons at Boston University School of Law

Faculty Scholarship

$10-2016$

\title{
The Obama War Powers Legacy and the Internal Forces that Entrench Executive Power
}

Rebecca Ingber

Boston University

Follow this and additional works at: https://scholarship.law.bu.edu/faculty_scholarship

Part of the President/Executive Department Commons

\section{Recommended Citation}

Rebecca Ingber, The Obama War Powers Legacy and the Internal Forces that Entrench Executive Power, 110 American Journal of International Law 680 (2016).

Available at: https://scholarship.law.bu.edu/faculty_scholarship/263 


\title{
THE OBAMA WAR POWERS LEGACY AND THE INTERNAL FORCES THAT ENTRENCH EXECUTIVE POWER
}

\author{
By Rebecca Ingber*
}

As we contemplate the incoming presidential administration, we stare ahead into uncharted space. It may seem as though recent history leaves us unprepared for what lies ahead. What can a discussion of the Obama war powers legacy, and the transition from the Bush to Obama administration, tell us about a transition from Barack Obama to the next president, and beyond?

Yet there are lessons here. No one can predict precisely how the president-elect and the team that is installed will confront the rule of law or grapple with the bureaucratic norms that I discuss in this paper. But systemic forces exist inside the executive branch that influence presidential decision-making in each modern administration and, barring a total reimagining of the executive branch, will operate on administrations to come. These internal forces include mechanisms and norms that fall within two broad categories: (1) those that favor continuity and hinder presidents from effecting change, and (2) those that incrementally help ratchet up claims to executive power.

These two sets of features operate together as a slow, staircase-like, one-way ratchet, over time expanding and then entrenching assertions of power. They do not always compel an escalation in claims to power, and, in fact, the forces of continuity may rein in attempts to exceed prior claims to authority. But they make it exceedingly difficult to withdraw such claims once made. Executive power claims do not swing in lockstep with the pendulum of political change. The weight may not fly as high (toward aggrandized power) as it might without these internal forces in place, but it is also unlikely to swing backward in the opposite direction without external pushback. Thus, when a president comes to office promising to dial back the prior administration's claims to power, as did Obama, and as might future presidents once again, those institutional features favoring continuity and those favoring executive power operate in tandem to entrench the executive power claims that the president inherits. This incremental aggrandizement is our long-term challenge, and its effects extend beyond the limits of any one presidential administration.

The Obama war powers legacy is inextricably entwined with the story of national security lawyering over the course of the last decade and a half. As Obama came to power, his supporters envisioned the new administration remedying what, in their view, had been-to put it plainly - an era of lawlessness in presidential war powers. This account of the Bush era was not simply a matter of policymakers ignoring legal restraints. Rather, lawyers were themselves at

* Associate Professor, Boston University School of Law. I am grateful to Curtis Bradley, Ashley Deeks, Jack Goldsmith, Marty Lederman, David Pozen, Daniel Richman, Robert Sloane, and participants at a BU Law faculty workshop, along with the Columbia Law School National Security Law workshop, for comments on drafts. For excellent research assistance, I thank Karen Leon, Ilya Feoktistov, and Kristen Queenan. 
the core of this story. These executive branch lawyers, the narrative went, manipulated (or were pressed into manipulating) internal decision-making processes to stifle dissent and to legitimize unlawful behavior. ${ }^{1}$ They did so, not by disregarding law entirely, but rather through their own instrumental and creative legal interpretations. ${ }^{2}$

If lawyers bore the blame for the excesses of the Bush administration, lawyers were also the hope for redemption in the next. Obama officials came into power shouldering a responsibility for righting what they viewed as the tainting of executive branch legal institutions. Nearly eight years later, the Obama legacy is itself not untainted by legal controversy over wartime practices, though it pales in comparison to what one of the presidential candidates has promised. ${ }^{3}$ Shadows of the Bush-era controversies have colored every aspect of the Obama executive branch's prosecution of the war and have framed the way that many view both what they endorse and what they condemn. Some have pointed to Obama's embrace of a wartime model for fighting some terrorist groups as evidence that the practices of that earlier era were legitimate, or at least understandable; that is, these issues were simply more difficult than outsiders cared to admit. ${ }^{4}$ Others have fought that perception and have declared a real break with Bush-era practices, warning against drawing false equivalencies between these administrations that future proponents of executive power might exploit. ${ }^{5}$

I do not intend to settle those debates in this essay. Rather, I hope to examine some overlooked reasons for continuity and change in executive branch decision-making, which will also affect presidential transitions going forward. I claim no special insight as to whether Obamathe-individual has been personally satisfied with where the dust has settled on each of these legal questions or whether the administration's ultimate substantive positions are those that he would have chosen at the outset. My focus is instead on the structural and institutional features of executive branch legal decision-making that often go overlooked in debates about the ideologies and intentions of presidents and their administrations but that have a significant influence on the executive's ultimate legal positions.

These internal features are significant not only as a partial explanation for Obama-era legal positions but also for what they portend for presidents to come. We should consider their import for the incoming presidential administration, and — should the incoming administration stake out aggressive claims to executive power - the import of these features will be particularly salient for the end of that administration and the subsequent transition into the

${ }^{1}$ See, e.g., Harold H. BrufF, Bad AdviCe: Bush's LaWyers in THE WAR ON TERror (2009); JACK GOLDSMITH, THE TERROR PRESIDENCY: LAW AND JUDGMENT INSIDE THE BUSH ADMINISTRATION (2007).

${ }^{2}$ BRUFF, supra note 1, at 237-56; GOLDSMITH, supra note 1, at 141-72 (discussing the internal process and faulty legal reasoning underlying the OLC "torture memos").

${ }^{3}$ See David Cole, The Drone Presidency, N.Y. REV. BOOKS, Aug. 18, 2016, at 19; see also, e.g., Donald Trump Says Terrorists' Families Should Be Targets, N.Y. TIMES, Dec. 2, 2015, at http://www.nytimes.com/politics/firstdraft/2015/12/02/donald-trump-says-terrorists-families-should-be-targets (quoting then-candidate Trump as arguing that the United States should target— "take out" - the civilian families of fighters of the Islamic State in Iraq and Syria (ISIS)).

${ }^{4}$ See, e.g., Remarks of John B. Bellinger III, Rule of Law Symposium, International Bar Association, Vancouver, Canada (Oct. 8, 2010), at http://files.arnoldporter.com/rule\%20of\%20law\%20symposium_john\%20bellinger. pdf; Jack Goldsmith, Obama Has Officially Adopted Bush's Iraq Doctrine, Time, Apr. 6, 2016, at http://time.com/ 4283865/obama-adopted-bushs-iraq-doctrine.

5 See, e.g., Marty Lederman, The Egan Speech and the Bush Doctrine: Imminence, Necessity, and "First Use" in the Jus ad Bellum, JUST SECURITY (Apr. 11, 2016), at https://www.justsecurity.org/30522/egan-speech-bushdoctrine-imminence-necessity-first-use-jus-ad-bellum; Dawn E. Johnsen, When Responsibilities Collide: Humanitarian Intervention, Shared War Powers, and the Rule of Law, 53 HOUS. L. REV. 1065, 1110 (2016). 
administration that follows. That future president will come into office inheriting the power accrued by his or her predecessor. And a new president inclined to dial back a predecessor's aggressive claims to power will find himself or herself constrained by the very internal forces that I discuss in this paper, forces that operate vigorously not only to preserve and protect executive power but also to resist attempts to diminish that power. Actors external to the executive - the courts and Congress - can successfully reverse executive aggrandizement. But forces internal to the executive branch generally confront executive aggrandizement successfully only when faced with such assertions in the moment. The internal mechanisms for continuity hinder novel claims to power primarily when such claims are, in fact, novel. Subsequently, the forces for continuity and the forces that protect and entrench executive power work in tandem to impede a president from dialing back claims to power inherited from a predecessor.

An additional relationship both amplifies and checks this one-way ratchet. Generally, the institutional features of executive branch legal decision-making are more enduring than the ideology of any given presidential administration, but they are not all ironclad. And it may come as no surprise that an interest in asserting novel claims of authority at times goes hand in hand with a willingness to circumvent, when feasible, some of these internal norms of executive branch decision-making. It is perhaps for this very reason that the traditional Madisonian checks on the president kick into gear most effectively to confront executive power when faced with an administration that seems to be skirting these norms. The internal and external checks on executive power must work together in a kind of symbiosis. Reasserting these external checks will be the task ahead for the courts and Congress and civil society. And should this next presidential administration result in an accretion of aggrandized executive power, the internal forces of entrenchment will be a challenge for future presidents seeking to reverse course.

\section{LAW AND POLICY; CONTINUITY AND CHANGE}

The Obama wartime lawyering legacy has been a mixed bag for those keen to prune the executive branch's claims of power. To be sure, the Obama presidency has been anything but a lawless one. (Nor, for that matter, was the Bush presidency, though notorious examples exist where it crossed the line. ${ }^{6}$ ) Law and process permeate every decision of significance within the executive branch. And, despite real impediments to change, the Obama administration has made some significant substantive reforms in both law and policy. Under Obama, the U.S. government no longer reserves the right to mistreat wartime detainees. It no longer actively seeks to hold terrorism suspects in wartime detention indefinitely when it could prosecute them instead. But it has retained the overarching legal architecture for the conflict with certain terrorist groups-Al Qaeda and now the Islamic State in Iraq and Syria (ISIS) and their "associated forces" —as a matter of both domestic and international law. ${ }^{7}$ It has continued actively to conceive of that conflict in war terms. It has fought hard to retain the legal authority to detain prisoners at Guantánamo, even as it seeks to close the detention facility, and to prevent judicial

\footnotetext{
${ }^{6}$ See, e.g., Curtis A. Bradley, The Bush Administration and International Law: Too Much Lawyering and Too Little Diplomacy, 4 DUKE J. CONST. L. \& PUB. POL'Y 57 (2009); see also BRUFF, supra note 1, at 237-56; GOLDSMITH, supra note 1, at 141-72.

7 See, e.g., Rebecca Ingber, International Law Constraints as Executive Power, 57 HARV. INT'L L.J. 49 (2016) (dissecting the executive branch's legal architecture for the conflict with $\mathrm{Al}$ Qaeda and other associated groups).
} 
review of wartime detention elsewhere. ${ }^{8}$ And it has aggressively used force abroad, rather than criminal justice, to immobilize and, moreover, to target and kill suspected participants in this conflict, even when those targets are far from an active battlefield and even when they include American citizens. ${ }^{9}$

One can identify some continuity between administrations without necessarily accepting either the narrative for why this continuity exists or the extent to which it was and continues to be inevitable. Surely, the reasons for continuity between the Bush and Obama administrations are overdetermined. Perhaps some of the legal positions that the Bush administration took are easier to swallow when made by Obama, the president who won the Nobel Peace Prize shortly after taking office. The tide of domestic politics turned, creating new legal hurdles to Obama's attempts at reform. ${ }^{10} \mathrm{We}$ continue to face a significant terrorist threat. And some have argued that after years of public scrutiny of the president's practices in the face of that threat, including congressional and judicial pushback, we may have reached a well-tested equilibrium. ${ }^{11}$ Certainly, and perhaps most importantly, the Bush administration's positions evolved dramatically in direct response to that external pushback. Many policies and legal pronouncements of the early Bush years — military commissions by one-page executive order; treatment of detainees governed only by vague policy pronouncements, rather than law; inherent executive authority to use armed force against any organizational threat worldwidealready seemed "quaint," to borrow a term, even in 2008, let alone $2016 .{ }^{12}$

I do not seek in this paper to test these narratives. But they tell an incomplete story, grappling primarily with the external realities facing these presidents. The focus of this essay is the internal and, specifically, the internal dynamics of decision-making that influence the executive branch's ultimate legal positions.

In distinguishing "legal" positions, I refer not to the process by which the administration reaches decisions of any sort, but rather to the substantive legal positions that it takes. These legal positions can and do change, just as the administration's policy positions can and do change. When the legal question is complicated and when multiple reasonable interpretations

\footnotetext{
${ }^{8}$ See Respondents' Memorandum Regarding the Government's Detention Authority Relative to Detainees Held at Guantanamo Bay, In re Guantanamo Bay Detainee Litigation, Misc. No. 08-442 (D.D.C. Mar. 13, 2009), at https://www.justice.gov/sites/default/files/opa/legacy/2009/03/13/memo-re-det-auth.pdf [hereinafter March 13 Brief]; see also Brief for Respondents-Appellants, Maqaleh v. Gates, 605 F.3d 84 (D.C. Cir. 2010) (No. 09-5265), 2009 WL 6043972.

9 See, e.g., Memorandum from Acting Assistant Attorney General David J. Barron to Attorney General Eric H. Holder, Applicability of Federal Criminal Laws and the Constitution to Contemplated Lethal Operations Against Shaykh Anwar al-Aulaqi (July 16, 2010), available at https://www.justsecurity.org/wp-content/uploads/2014/06/ OLC-Awlaki-Memo.pdf; Cole, supra note 3, at 19 (contending that, under Obama, "[r]emote killing outside of war zones, it seems, has become business as usual").

${ }^{10}$ See, e.g., National Defense Authorization Act for Fiscal Year 2012, Pub. L. No. 112-81, 125 Stat. 1298 (creating hurdles for the executive in transferring detainees).

${ }^{11}$ Jack Goldsmith, POWer And Constraint: The ACCOUntable Presidency After 9/11 (2012).

12 See, e.g., Memo from White House Counsel Alberto Gonzales to Pres. George W. Bush (Jan. 25, 2002) (asserting that the "war against terror is a new kind of war[,]" which "renders obsolete [the Geneva Conventions'] strict limitations on questioning of enemy prisoners and renders quaint" other provisions such as the provision of commissary privileges or athletic uniforms). In 2006, the U.S. Supreme Court rejected the government's theory that the Geneva Conventions did not apply to the conflict as a matter of law and held that, at a minimum, common Article 3 of the Conventions, which includes, inter alia, prohibitions on the mistreatment of detainees, applies to the conflict with Al Qaeda. See Hamdan v. Rumsfeld, 548 U.S. 557 (2006); see also Johnsen, supra note 5, at 1108 (suggesting that comparison between Bush and Obama "depends in part on whether one is looking at the beginning or end of the Bush Administration").
} 
are possible, the choice of which legal position to take is itself a policy decision. Furthermore, both statements of law and statements of policy can constrain the executive branch. ${ }^{13}$ Thus, some overlap exists between the two, and it is easy to see how the line between law and policy can be tough to navigate. But the distinction between them is essentially this: when the administration takes a legal position, it is saying that it is bound to take or not to take a particular action, and bound by some external or fixed source. ${ }^{14}$ When the administration takes a policy position, it is saying that it has discretion to act in a variety of ways (within the bounds of the prior legal position) but that it is choosing to act in accordance with this particular policy pronouncement.

The line between law and policy in this realm is sometimes difficult to identify, but the distinction is important. As Ashley Deeks explores in her contribution to this Agora, the Obama administration made many substantive policy changes (even if fewer or less aggressive than some would have liked), and many have a quasi-law-like quality, but the Obama administration has retained many of the critical wartime legal positions of the prior administration. ${ }^{15}$ Most notably, the Obama administration has generally retained the late Bush-era legal theories for targeting and detaining individuals in the conflict with Al Qaeda (and now ISIS), while crafting policy overlays that provide additional protections for individuals and constraints on the U.S. government. ${ }^{16}$

Many reasons exist for this distinction between law and policy. Scholars have suggested instrumental reasons to explain this approach. ${ }^{17}$ The next two parts of this essay discuss the structural and institutional features that underlie this distinction and drive executive behavior toward incremental aggrandizement and entrenchment of executive power.

\section{INSTITUTIONAL BIASES DRIVING LEGAL DECISION-MAKING}

This part explores biases resulting from the institutional features of executive branch legal decision-making that influence the substantive legal positions that the executive takes. Some features affect the structure of the deliberative process. Others are rules for how decisions ought to be made or memorialized. I distinguish here between those features that favor continuity in executive positioning (which I term "neutral friction"), and those that favor inexorable, if incremental, increases in executive claims to power over time (which I term "power-aggrandizing" features).

These features vary according to how easily they may be manipulated. Some are hard-baked into the legal architecture of the executive branch. Others may be more easily cast aside. Obama inherited some of these features from Bush; others, he revitalized himself. All of the features

${ }^{13}$ Some have argued that nonlegal constraints may well be as effective or better than legal constraints for certain kinds of high-level decisions. See Richard H. Pildes, Conflicts Between American and European Views of Law: The Dark Side of Legalism, 44 VA. J. INT'L. L. 145 (2003).

${ }^{14}$ This distinction is complicated further by the executive's own regulations or executive orders.

${ }^{15}$ Ashley S. Deeks, The Obama Administration, International Law, and Executive Minimalism, 110 AJIL 646 (2016) (terming this approach "executive minimalism").

${ }^{16} \mathrm{Id}$. For a comparison of the Bush and Obama legal standards for detention, compare Boumediene v. Bush, 583 F.Supp.2d 133, 134 (D.D.C. 2008), with March 13 Brief, supra note 8. The former is an example of a Bush-era position that was itself narrowed through litigation. Judge Richard Leon crafted a standard based on, but narrowed from, that proposed by the government under Bush.

${ }^{17}$ See, e.g., Deeks, supra note 15. 
that I address have helped guide decision-making under the Obama administration toward protection of executive power. These institutional features are not intended as justification for a president's ultimate positions; rather, they provide partial explanations for why any given presidential administration might find it difficult to part from — and, in particular, to scale down-the specific claims on executive authority from the administration that came before.

\section{Executive Power Versus Political Control}

Before I turn to these structural features, I will briefly address the language of presidential power. I distinguish here between two types of presidential power, which have been conflated in discussions about the internal dynamics of executive branch decision-making. The first type is the focus of Elena Kagan's "Presidential Administration": the ability of the president to exert top-down control over decision-making. ${ }^{18}$ Kagan focused on political control of policy making, but this concept is equally applicable to legal decision-making. The National Security Council-led "Lawyers Group," discussed below, is an example of heightened White House control of legal decision-making, as compared to one driven by the U.S. Department of Justice's Office of Legal Counsel (OLC) or career litigators within the Department of Justice (DOJ). A second and distinct type of presidential power is the executive's claims to authority vis-à-vis the courts or Congress. The distinction is simple. The first addresses a power dynamic pitting the political players at the White House or the politically appointed heads of different executive branch components against the broader bureaucracy. This dynamic is an internal struggle. The second pits the executive branch as a whole against the other external branches of government. We might call the first "political control" and the second "executive power."

These distinct power dynamics set up different and, at times, conflicting institutional impulses. When political actors wrest control from the career bureaucracy for the purpose of asserting aggressive claims to executive power, these two types of power operate together. White House officials may extend their reach into the bureaucracy for the direct purpose of influencing more executive-aggrandizing legal positions, such as the Bush administration's interference in OLC lawyering over the treatment of detainees, leading to assertions that the president could act without or even in contravention of Congress during war. ${ }^{19}$ In that case, political control is not the desired end, but rather a means to achieve this second type of power, which is manifest in heightened assertions of executive power.

As fodder for the theory that White House intervention lends itself toward executive power aggrandizement, scholars have thoroughly dissected reports of the decision-making process surrounding the legality of the Libya intervention and its continuation beyond the War Powers Act sixty-day mark. ${ }^{20}$ If reports of that process are accurate, they suggest that the White House chose to disregard the legal advice of OLC and the Pentagon over the strictures of the War Powers Act, in favor of advice by White House counsel and the U.S. State Department legal adviser,

\footnotetext{
${ }^{18}$ See Elena Kagan, Presidential Administration, 114 HARV. L. REV. 2245 (2001).

${ }^{19}$ Daphna Renan calls such political interference in legal decision-making "politicized formalism.” Daphna Renan, The Transformation of Executive Branch Legalism (2016) (unpublished manuscript) (on file with author).

${ }^{20}$ War Powers Act of 1973, 50 U.S.C. $\$ 1544$ (2000); see also, e.g., Bruce Ackerman, Legal Acrobatics, Illegal War, N.Y. TIMES, June 21, 2011, at A27. Of course, the Pentagon's own legal advice in that instance may equally have been influenced by its policy preferences rather than a "best" view of the law.
} 
who interpreted the president's authority more permissibly. ${ }^{21}$ Some scholars have pointed to these reports as evidence of a shift toward White House-centric decision-making, and many have critiqued the Libya decision-making process as the White House's cherry-picking of legal advice in the service of sanctioning an aggressive claim to authority. ${ }^{22}$

Yet presidential control and aggressive claims to executive power need not operate in tandem. An administration's ideology on a particular matter may drive it in the opposite direction, and the career bureaucracy may be more inclined than political appointees to zealously protect executive power. In such cases, political actors seeking to intervene in the decisions of the career bureaucracy may do so for the purpose of asserting weaker, not greater, claims to power. For example, David Pozen reflects that Obama administration efforts to counteract the "excessive politicization of DOJ by the Bush II Administration"- a hands-off approach by the Obama appointees for fear of giving the appearance of "White House meddling" — resulted in an uptick by the Obama DOJ in the prosecutions of individuals alleged to have divulged classified information, where the administration might otherwise have limited those prosecutions. ${ }^{23}$ In another example, press reports suggest that, in 2011, career litigators at DOJ were set to file a brief in the Padilla case asserting that the president may have the power to place an American citizen arrested on American soil in military detention. ${ }^{24}$ According to these reports, White House officials did not want to assert such power and, despite prevailing norms against White House intervention in DOJ litigation decisions, pushed DOJ to remove that claim. ${ }^{25}$ In that case and others, White House intervention led to the imposition of more constraint on executive authority, in contrast to what a more politically independent process would have produced.

That the career bureaucracy may sometimes be more protective of executive power than any given political player is intuitive when one considers that the executive branch is predominantly made up of long-serving civil servants who may have a greater allegiance to the institution of the executive or to their particular agency component than do the political actors who serve it on a shorter-term basis. ${ }^{26}$ (Consider that when they are not serving in the executive branch, those political actors may be acting in opposition to the administration in power.) While these two types of power seeking may operate hand in hand, they are not interchangeable. And yet, as we have seen and may see again, a president inclined to make aggressive claims of power may be more willing than those inclined to dial back that power to circumvent some

${ }^{21} I d$.

${ }^{22}$ Id.; Trevor W. Morrison, Libya, "Hostilities," the Office of Legal Counsel, and the Process of Executive Branch Legal Interpretation, 124 HARV. L. REV. F. 62, 66 (2011) (identifying "[m]ost worryingly, the press reports claim that OLC's opinion was presented to the President as just one perspective on the 'hostilities' issue").

${ }^{23}$ David E. Pozen, The Leaky Leviathan: Why the Government Condemns and Condones Unlawful Disclosures of Information, 127 HARV. L. REV. 512, 591, 632-33 (2013) ("Notwithstanding the norm of declining to interfere with specific prosecution decisions, ... media leaking has historically been an area on which the White House has counseled caution.").

${ }^{24}$ Charlie SAVAGE, POWER WARS: InSIDE Obama's POST-9/11 PrESIDENCY 47, 155-56 (2015).

${ }^{25}$ Id.; Brief of the United States as Amicus Curiae at 20, Lebron v. Rumsfeld, 670 F.3d 540 (4th Cir. 2012) (No. 11-6480), available at https://www.aclu.org/legal-document/padilla-v-rumsfeld-amicus-brief-united-states (arguing nevertheless "that the military detention of a citizen, apprehended in the United States in a congressionally authorized armed conflict, was not clearly established to be unconstitutional at the time").

${ }^{26}$ Scholars have critiqued this feature of executive branch decision-making as, among other things, unaccountable and thus dangerous. See MiChaEl J. GLENNON, NATIONAL SECURITY AND DOUBLE GOVERNMENT (2014). 
of the long-standing norms and institutional features of the executive branch in order to consolidate political control for the purpose of effectuating those executive power ends.

\section{Neutral Friction Versus Power Aggrandizing Features}

The features that I discuss here tend to influence executive branch legal positioning in one of two directions. As noted, "neutral friction" refers to features that operate to constrain legal change generally, in any direction, without regard to substance. This class of features impedes the president's ability to change legal positions full stop, without regard to that administration's approach to executive power. ${ }^{27}$ In the Bush to Obama transition, this "neutral friction" created resistance for Obama officials who might have been inclined to move away from Bush legal positions, specifically here either to recalibrate past claims of executive power or to alter doctrinal positions on the domestic or international legal structure for the conflict with $\mathrm{Al}$ Qaeda.

A second category consists of features of executive branch lawyering that generally operate to tilt decision-making toward an incremental but inexorable ratcheting up of executive power. As noted, I refer to these features as "power aggrandizing."

Under this classification, only the latter group of structural features tilts toward executive aggrandizement without regard for the ideological proclivities of a particular administration. But taken together, these features act as a one-way ratchet. For an administration inclined toward novel, aggressive assertions of power, internal forces favoring continuity will hamper such assertions, while power-aggrandizing features will support them. In such an administration, these two sets of features are in tension. But in a transition from a presidential administration inclined toward aggrandized claims to power to one promising to pare down such claims, these two classes of institutional features come together to entrench-and, in some cases, even to advance-the existing legal positions favoring executive power.

\section{DECISION-MAKING FEATURES THAT FOSTER CONTINUITY OR AGGRANDIZEMENT} OF EXECUTIVE POWER

\section{Norms Against Politicization of Legal Decision-Making}

The executive branch legal decision-making sphere contains long-standing norms, or "conventions," 28 that in the aggregate suggest an aversion to the politicization of legal decisionmaking. These norms - formal and informal, written and unwritten, followed religiously and honored in the breach—are intended to shield legal decision-makers from a range of influences from partisan meddling to policy pressure. They typically favor continuity in executive branch positions and thus can be classified as neutral friction.

\footnotetext{
${ }^{27}$ General decision-making phenomena that impede change, like path dependency and status quo bias, play a role in neutral friction. See Oona A. Hathaway, Path Dependence in the Law: The Course and Pattern of Legal Change in a Common Law System, 86 IOWA L. REV. 601 (2001); William Samuelson \& Richard Zeckhauser, Status Quo Bias in Decision Making, 1 J RISK \& UNCERTAINTY 7 (1988).

28 See David E. Pozen, Self-Help and the Separation of Powers, 124 YALE L.J. 2, 27 (2014) (noting that constitutional conventions are "quasi-legal norms that organize the workings of government," which entail costs if violated).
} 
Norms against politicization take different forms according to office. OLC, for example, aspires to achieve legal decision-making insulated from policy preferences. ${ }^{29}$ Other offices seek freedom not from policy necessarily but from politics. ${ }^{30}$ Prosecutors in U.S. Attorney Offices scattered throughout the country expect to be shielded to some degree from DOJ headquarters, and from partisan politics more generally. For this reason, the Bush administration faced public outrage and internal investigations when it was seen as firing prosecutors for political reasons. ${ }^{31}$ At "main Justice," the DOJ headquarters in Washington, DC, the litigating divisions are dominated by career lawyers who shun political interference, even though such divisions are run by political appointees. ${ }^{32}$

Who is considered a political actor also varies across contexts. Theoretically, anti-politicization norms are a buffer between the career bureaucracy and political interference. But often this line is drawn not between political actors and civil servants, but rather between DOJ and the White House, even though the former is overseen by political appointees, and the latter is home to many civil-service detailees. Different expectations exist even among the political appointees at DOJ, where, for example, the solicitor general holds the last word on litigation but is expected to be more removed from questions of politics or policy, on which he may defer to the attorney general. ${ }^{33} \mathrm{We}$ might envision a spectrum of accepted political or policy motivation ${ }^{34}$ among executive branch legal decision-makers, from the president at one end, to White House counsel to OLC to civil servants working in agency general-counsel offices to career prosecutors at the other extreme.

The extent to which these norms are regularly followed or truly shield actors from political interference depends heavily on context. But even when political actors counteract these norms, they are hurdles that such actors must surmount. When a judge asked the Obama administration for its reconsidered detention standard in the Guantánamo habeas cases in early 2009, the litigators filing the briefs were to be the very same who had filed them for the Bush administration in 2008. ${ }^{35}$ When the Obama administration sought a plea deal for a controversial child-soldier case in the restarted military commissions, it faced formal hurdles to intervention in the work of the career prosecutors-hurdles that Congress had put in place in response to Bush-era interference. ${ }^{36}$

\footnotetext{
29 See Memorandum from Acting Assistant Attorney General David J. Barron to Attorneys of the Office, Best Practices for OLC Legal Advice and Written Opinions (July 16, 2010), available at https://www.justice.gov/ sites/default/files/olc/legacy/2010/08/26/olc-legal-advice-opinions.pdf (stressing the independence of OLC legal advice, even when it might undercut the objectives of policymakers) [hereinafter OLC Best Practices].

${ }^{30}$ See, e.g., UNITED STATES ATTORNEY'S MANUAL sec. 3-2.140 (1997), at https://www.justice.gov/ usam/usam-3-2000-united-states-attorneys-ausas-special-assistants-and-agac\#3-2.140 (admonishing that U.S. Attorneys implement DOJ policy, but stressing "the need for their impartiality in administering justice [which] directly affect[s] the public's perception of federal law enforcement”); U.S. DEPARTMENT OF JUSTICE, AN INVESTIGATION INTO THE REMOVAL OF NINE U.S. ATTORNEYS IN 2006, at 325 (Sept. 2008), available at https:// oig.justice.gov/special/s0809a/final.pdf (criticizing the Bush administration's use of "political partisan considerations" in removing certain U.S. Attorneys).

${ }^{31}$ U.S. DEPARTMENT OF JUSTICE, supra note 30, at 325-26.

32 See Rebecca Ingber, Interpretation Catalysts and Executive Branch Legal Decisionmaking, 38 YALE J. INT'L L. 359, $421 \mathrm{nn} .95-109$ (2013).

${ }^{33} \mathrm{Id}$. at 421 n. 109.

${ }^{34}$ Consideration of political versus policy preferences is itself a distinct question, which differs in acceptance according to role.

35 See Rebecca Ingber, Co-belligerency and War Powers, 42 YALE J. INT'L L. (forthcoming 2017).

${ }^{36}$ Charlie Savage, U.S. Wary of Example Set by Tribunal Case, N.Y. TIMES, Aug. 28, 2010, at A1; SAVAGE, supra note 24 , at $317-19$.
} 
These norms are long-standing, but they are not immutable. The incoming Obama administration sought to resurrect buffers for legal decision-makers after the Bush-era critiques of political interference. But they faced an inevitable tension between shielding legal guidance from political interference and trying to change the substantive positions of the prior administration. An incoming administration that wishes to circumvent these hurdles will, in many cases, be able to do so- - with sufficient energy and resources- but, as we have seen in the past, significant circumvention of these norms will surface and meet with external political resistance.

\section{Norms Against Written Redlines}

A significant feature in the power-aggrandizing category is the tacit soft norm against written redlines - explicit limits on executive power-included alongside endorsement of authority within legal memoranda. The norm against written redlines does not operate as a prohibition and is certainly not thought of as such. But the contextual pressures of legal guidance within the executive branch, the ways in which it is sought and provided, the reasons for seeking legal guidance, and even the professional practice of lawyering itself ultimately entail that executive branch lawyering rarely produces written limits on the president's lawful sphere of activity.

To begin, most legal guidance within the executive branch is not written at all; rather, it is provided orally, informally from lawyer to client. ${ }^{37}$ In areas where the law is complex or multiple reasonable approaches exist, as with much national security lawyering, lawyers typically provide an assessment of risks and try to steer their clients toward policy choices that rest on sounder legal footing. An agency lawyer may often be in a position to affirmatively "clear" the legality of an action, but may rarely have to give a firm "no," simply because she may have steered the client away from the legal line well before it became a close call. Most executive branch lawyers prefer to avoid chalk on their cleats. ${ }^{38}$

There is nevertheless much written legal guidance within the executive branch, most notably from OLC. The practice of OLC is often to provide oral guidance, but it will prepare a written opinion when there is a "practical need" for one. ${ }^{39}$ A "practical need" for a written "no" is a rarity for executive actors. ${ }^{40}$ It would be impossible to conduct an empirical study comparing the ratios of how often negative legal advice is memorialized in comparison to positive legal advice because we cannot know how much legal advice goes unwritten. ${ }^{41}$ But executive officials

${ }^{37}$ The "client" here is typically the policymaker requesting legal guidance from agency counsel or from DOJ.

${ }^{38}$ Cf. Michael V. Hayden, Director of the Central Intelligence Agency, CIA Director's Address at Duquesne University Commencement (May 4, 2007), at https://www.cia.gov/news-information/speeches-testimony/2007/ cia-directors-address-at-duquesne-university-commencement.html.

${ }^{39}$ See OLC Best Practices, supra note 29, at 3.

${ }^{40}$ See Richard H. Pildes, Law and the President, 125 HaRV. L. ReV. 1381, 1399 (2012) (noting that "one will never see an OLC memo" determining that the president lacked the power to pursue a particular course of action because the "White House would neither need nor want a formal OLC opinion that [reached that conclusion]"). Trevor Morrison conducted a study of published OLC opinions (an admittedly skewed sampling) and found that $21 \%$ included real limitations on the White House's proposed course of action. Trevor W. Morrison, Constitutional Alarmism, 124 HARV. L. REV. 1688, 1717 (2011).

${ }^{41}$ See, e.g., Morrison, supra note 40, at 1719 ('OLC's 'facilitative approach' means that the rate at which its written opinions say yes to the President can be highly misleading. This is because many of OLC's no's never result in written opinions."). 
are surely less likely to need or request a written opinion stating that they cannot do something. ${ }^{42}$ Indeed, when a policy client's preferred course of action is deemed unlawful, even OLC's preferred approach is not to memorialize that negative advice but instead "to suggest modifications that would cure the defect, and . . . to [help] craft lawful alternatives." 43

To be sure, examples to the contrary exist. ${ }^{44}$ A recent OLC memo blessing the president's authority to lessen enforcement of immigration violations outlines limits on that authority. ${ }^{45}$ We can speculate on the reasoning behind that inclusion of written redlines; one possibility is the anticipation of judicial and political oversight, along with a belief that the president's policy and legal justifications would fare better if they contained clear outer limits. ${ }^{46}$ Whatever the reason, written line-setting is the exception and not the rule.

This practice may stem in large part from legal professional norms in which decision-makers address the question before them and no more. OLC attorneys, in particular, view their position as similar to judges, who are charged with deciding only the specific case or controversy before them, not with opining on the hypothetical outer limits of the law. ${ }^{47}$ Indeed, because OLC "is frequently asked to opine on issues of first impression that are unlikely to be resolved by the courts," its advice will often "be the final word on the controlling law." ${ }^{48}$ One critical difference, however, which distinguishes OLC from an independent judiciary, is that when judges external to the executive branch tell the president "no," they memorialize it in a written opinion.

The inevitable result of the norm against written redlines is that the archives for future government attorneys will include plenty of precedent-setting memoranda supporting action, but fewer clear limits. Trevor Morrison has studied OLC practices specifically and has recognized the risk that

because OLC's written opinions are more readily searchable than its oral answers, new OLC lawyers might overread certain written opinions to support the legality of policies or actions OLC had earlier deemed unlawful in oral advice. This could yield a jurisprudence that is more one-sided than OLC itself has intended. ${ }^{49}$

Considering how lawyers address novel questions, by comparing new scenarios to old precedents, this lack of written redlines means that over time new lawyers have only those opinions authorizing action on which to build and draw analogies. One can readily envision how small

42 Pildes, supra note 40, at 1399.

43 Walter E. Dellinger eT Al., Principles to Guide The OfFice OF Legal Counsel (2004), reprinted in Dawn E. Johnsen, Faithfully Executing the Laws: Internal Legal Constraints on Executive Power, 54 UCLA L. REV. 1559, 1603, 1609 (2007); Morrison, supra note 40, at 1719.

${ }^{44}$ See Morrison, supra note 40, at 1717.

${ }^{45}$ Memorandum from Principal Deputy Assistant Attorney General Karl R. Thompson to Secretary of Homeland Security Jeh Johnson and White House Counsel W. Neil Eggleston, The Department of Homeland Security's Authority to Prioritize Removal of Certain Aliens Unlawfully Present in the United States and to Defer Removal of Others (Nov. 19, 2014), at https://www.justice.gov/sites/default/files/olc/opinions/attachments/2014/11/20/ 2014-11-19-auth-prioritize-removal.pdf.

46 See Transcript of Oral Argument, Solicitor General Donald B. Verilli, United States v. Texas, 136 S.Ct. 1539 (2016) (No. 15-674), available at https://www.supremecourt.gov/oral_arguments/argument_transcripts/15-674_ h3dj.pdf (noting the limits on the legal justification contained within the OLC memo).

${ }^{47}$ Muskrat v. United States, 219 U.S. 346 (1911).

48 OLC Best Practices, supra note 29, at 1.

${ }^{49}$ Morrison, supra note 40, at 1720. 
incremental extensions of precedents in one direction can build over time to a significant expansion of power.

Of course, one can read into an OLC opinion the likely contours of where redlines may exist, just as one may read likely redlines into a Supreme Court opinion upholding an executive action. Yet genuine written redlines, when they exist, surely act as more effective constraints on future presidents and policymakers than hoping they read the implicit limitations hidden between the lines. And as for divining the Supreme Court's implicit redlines, trying to push the envelope on that Supreme Court opinion in the future could ultimately result in a constraining binding decision, which the executive generally tries to avoid..$^{50}$ Pushing the envelope on an OLC opinion, by contrast, entails simply picking up the phone and asking OLC; there is little risk involved in receiving an informal internal "no," and thus there is little benefit to executive policymakers in prophylactically steering clear of the line.

Outside of OLC, the ad hoc state of recordkeeping generally within the agency General Counsel offices, and within more informal processes like the Lawyers Group, compounds this phenomenon. ${ }^{51}$ The Lawyers Group may sometimes produce an exchange of memos, ${ }^{52}$ which might include views about where the redlines should be drawn (as did the "War Council" process of the Bush administration, once the State Department legal adviser caught wind of $\mathrm{it}^{53}$ ), but such work product is not precedent. Individual agencies may also produce internal memoranda or emails discussing legal issues, and they often follow their own institutional precedents, but none is as formalized as OLC.

Recordkeeping defects are not limited to written redlines; the defects also reduce the written record of legal decisions authorizing actions. But incentives are greater to preserve a file of approvals. Policymakers, in particular, who need to demonstrate legal clearance on their proposed action are more inclined to retain a legal memorandum authorizing action than one applying the brakes. ${ }^{54}$ Moreover, legal authorization may be demonstrated-or at least assumed - by observable action. ${ }^{55}$ By contrast, a lack of action alone may rest on multiple motivations; it does not demonstrate or even suggest a lack of legal authority. ${ }^{56}$

50 See Ashley S. Deeks, The Observer Effect: National Security Litigation, Executive Police Changes, and Judicial Deference, 82 FORDHAM L. REV. 827 (2013).

51 See Oona A. Hathaway, The Rule of Law in National Security Lawyering (2016) (unpublished manuscript) (on file with author) (contrasting formal OLC opinions with "more informal lawyers group papers"). Charlie Savage has reported that the group sometimes produces short unsigned memoranda. See SAVAGE, supra note 24, at 628.

52 See SAVAGE, supra note 24, at 643-45 (discussing exchange of memos on Libya).

${ }^{53}$ Memorandum from Department of State Legal Adviser William H. Taft IV to White House Counsel Alberto R. Gonzales, Comments on Your Paper on the Geneva Convention (Feb. 2, 2002), available at http://www. nytimes.com/packages/html/politics/20040608_DOC.pdf.

${ }^{54}$ I am grateful to Ashley Deeks for suggesting this and other insights.

55 There are exceptions. Under the Clinton administration, the legal adviser explicitly declined to justify the Kosovo intervention as a matter of international law. That he felt the need to do so suggests that he thought silence might imply legal embrace. See Michael J. Matheson, Human Rights and Humanitarian Intervention: The Legality of the NATO-Yugoslav-Kosovo War, 94 AM. SOC'Y INT'L L. PROC. 301 (2000).

56 We cannot know what role legal constraints_-versus politics and other factors_-played in Obama's decision to defer to Congress on the use of force against Syria after its president Bashar al-Assad deployed chemical weapons. That example will not constrain future presidents in the same way as would a written memorandum deeming such action unlawful. Butsee Michael D. Ramsey, Constitutional War Initiation and the Obama Presidency, 110 AJIL 701, 714-15 (2016) (arguing that "the nonuse of force in Syria constitutes a significant constraining precedent," despite noting that the president had "insisted (without much elaboration) that he had independent authority to order air strikes"). 
This norm against written redlines is perhaps the starkest contrast between the internal and external separation of powers. The problem is not necessarily that lawyers fail to say "no" or that their "no's" fail to constrain executive action. To the contrary, internal advice about legal risk alone may generate a prophylactic buffer zone around executive action, resulting in policies that steer far clear of the legal line. ${ }^{57}$ But over the arc of history, a culture of memorializing primarily the affirmative precedents — and a dynamic in which the executive itself largely interprets the law that binds the executive branch-lead to an incremental but inexorable incline in claims to executive power.

\section{Lawyering by Committee}

One of the most significant internal process features that the Obama administration revitalized has been a move away from exclusive legal decision-making by a small number of actors, toward a more inclusive and representative group. Lawyers from each of the relevant national security agencies comprise the "Lawyers Group," as it is known within the executive branch. ${ }^{58}$ Decisions are typically, or at least ideally, made by consensus. ${ }^{59}$ The Lawyers Group as it operates in practice has features that fall both within the neutral friction and power aggrandizing categories, which I break out in the subsections below.

The Lawyers Group is not an entirely new phenomenon; presidents have relied upon versions of a National Security Council-led lawyers group for national security legal decisionmaking at least since the $1990 \mathrm{~s} .{ }^{60}$ But the Obama administration has placed a greater emphasis on this interagency process, driven in part by charges that the Bush administration had selectively channeled legal decisions to an exclusive coterie of senior lawyers. Thus, where the Bush "War Council" had notoriously stifled dissent by cutting out particular agencies like the State Department, the Obama Lawyers Group has prioritized inclusiveness. ${ }^{61}$

The Lawyers Group approach is also in tension with the unitary decider model of offices like OLC. Some scholars have suggested that, under Obama, the Lawyers Group move has engendered more White House-centric, top-down legal decision-making ${ }^{62}$ and, relatedly, that it may

57 See Donald C. Langevoort \& Robert K. Rasmussen, Skewing the Results: The Role of Lawyers in Transmitting Legal Rules, 5 S. CAL. INTERDISC. L.J. 375 (1997) (demonstrating the tendency of lawyers to overstate legal risk).

${ }^{58}$ Scholars have only recently begun to examine the Lawyers Group process under Obama. See Hathaway, supra note 51; Jennifer N. Marett, The National Security Council Legal Adviser: Crafting Legal Positions on Matters of War and Peace, 8 J. NAT'L SECURITY L. \& POL'Y 153 (2015) (drawing on a speech by former National Security Council legal adviser Mary De Rosa). An early discussion of the Obama Lawyers Group can be found here: Robert Chesney, Podcast Episode \#8: Brigadier General Richard Gross on the Role of the Legal Advisor to the Chairman of the Joint Chiefs of Staff, LAWFARE (Apr. 9, 2012), at http://www.lawfareblog.com/2012/04/lawfare-podcast-episode-8-brigadiergeneral-richard-gross-on-the-role-of-the-legal-advisor-to-the-chairman-of-the-joint-chiefs-of-staff.

59 SAVAGE, supra note 24, at 693-94.

${ }^{60}$ John Bellinger, Charlie Savage and the NSC Lawyers Group, LAWFARE (Nov. 8, 2015), at https://www. lawfareblog.com/charlie-savage-and-nsc-lawyers-group; THE 9/11 COMMISSION REPORT: FINAL REPORT OF THE NATIONAL COMMISSION ON TERRORIST ATTACKS UPON THE UNITED STATES 293 (2004), available at https://9-11 commission.gov/report (discussing a "Deputies Committee" meeting's conclusion on the legality of killing Osama bin Laden by Predator drone); H.R. REP. NO. 102-1094, at 73 (1992) (discussing allegations that "the White House and the National Security Council (NSC) formed a high level interagency lawyers group to discourage, frustrate, evade, and thwart Congressional investigations of the Administration's policy toward Iraq").

${ }^{61}$ GOLDSMITH, supra note 1.

${ }^{62}$ See Hathaway, supra note 51. 
have undermined the role of OLC. ${ }^{63}$ Under those scholars' accounts, this approach has resulted in claims of more, rather than less, executive power. ${ }^{64}$ Yet that may not always be the case. Certainly, as compared to a pure OLC approach, the Lawyers Group brings decision-making under the aegis of the White House National Security Council and thus increases political control of that decision-making. As I discuss above, however, greater political control does not necessarily lead to greater claims of executive power. ${ }^{65}$ The extent to which it does so depends on the specific administration, the individuals involved at the White House, their approaches to executive power, and the particular challenges that they may face at any given point in time that trigger legal decision-making.

Dilution of Specialized Expertise. One constant feature of the inclusive, committee lawyering approach that is consistent with the above critiques, however, is that it dilutes the power of each individual office. This dilution potentially results in a power-aggrandizing effect if one of those offices might otherwise - if asked directly — be inclined to raise legal impediments to action. When each member of the group has an equal stake and competence, giving each an equal vote makes sense. But with some matters, one office may have special claim or expertise, like OLC on matters of constitutional law, or the State Department's Legal Adviser's Office (L) on matters of international law. When OLC or L is not the ultimate decision-maker on a matter, but rather one voice among many at the table, this approach dilutes not only that particular actor's vote but also the effect of the expertise that the office brings to bear. In a group setting, the authoritative expert office's view of the constitutionality of an act or its compliance with international law may be simply one of many factors guiding the group's legal thinking, rather than the final word.

Political control of decision-making per se does not necessitate greater claims of executive power. But the dilution of offices that define their role as speaking definitively to domestic or international law constraints on the president, including vis-à-vis other agency lawyers who may view their roles as more facilitative, may have the effect of tilting legal guidance as a whole toward a more permissive disposition.

Process as Impediment to Change. Adding decision-makers to the table inevitably creates a collective-action problem to decision-making. This feature of committee lawyering is a simple but effective impediment to change. ${ }^{66}$ It contrasts starkly not only with the intentionally process-flouting "War Council" approach of the Bush years but also with the more well-established OLC model. ${ }^{67}$ Indeed, the OLC model, though it emphasizes precedent, ${ }^{68}$ has proven capable of making significant change, even to rein in executive power, unencumbered by the collective-action problems of the Lawyers Group. Under both the Bush and Obama administrations, attorneys running that office acted to overturn memos written by predecessors sanctioning the mistreatment of wartime detainees. ${ }^{69}$

${ }^{63}$ Jack Goldsmith, The Decline of OLC, LAWFARE (Oct. 28, 2015), at https://lawfareblog.com/decline-olc; Renan, supra note 19; Ackerman, supra note 20, at A27.

${ }^{64}$ E.g., Ackerman, supra note 20, at A27.

${ }^{65}$ See supra text accompanying notes $18-26$

${ }^{66}$ See, e.g., SAVAGE, supra note 24, at 693 (“[T] he Obama administration's restoration of a slow and careful decision-making process made it harder to dislodge the new status quo Bush had created.”).

${ }^{67}$ OLC's practice is so insular that its attorneys do not circulate drafts outside the office. See OLC Best Practices, supra note 29 , at 4 .

${ }^{68}$ See Trevor W. Morrison, Stare Decisis in the Office of Legal Counsel, 110 COLUM. L. REV. 1448 (2010).

${ }^{69}$ E.g., GOLDSMITH, supra note 1, at 141-72 (discussing Goldsmith's decision to withdraw the original "torture memos" and simultaneously resign from the office); Memorandum from Acting Assistant Attorney General David 
Committee lawyering can be neutral friction; it creates hurdles to change, regardless of substantive position. But presidents have, at times, circumvented the hampering effect of inclusive committee lawyering in order to change the substantive legal positions of the executive, both to rein in and to expand executive power. Moreover, collective action impediments work in both ways, depending on how the question is framed. If a group of lawyers is asked, "Can I move forward?" a committee process may slow action. If the group is asked instead, "Is there anything standing in the way of action?" a committee process may suppress dissent and impede the imposition of meaningful constraints on presidential action.

Ambiguity as Power. A significant power-aggrandizing feature of committee lawyering is the tendency of group decision-making to result in ambiguous claims of legal authority. That ambiguity, in turn, results in increased discretion, and therefore power, for the president and future executive actors.

The Lawyers Group is comprised of lawyers of divergent legal views and instincts, who represent agencies that have differing and sometimes opposing interests at stake. But the group is under significant pressure to produce an output; questions of national security are at stake. When multiple actors disagree, this dynamic leads to reaching a decision according to the lowest common denominator-the simplest statement that can draw sufficient agreement from the room. This dynamic may also mean papering over differences by producing a statement that is intentionally ambiguous. Such "constructive ambiguity" 70 permits the group to reach consensus necessary for the president or an executive official to act. But it means leaving on the table legal alternatives that individually do not garner a majority vote; going forward, they remain quasi-available. Once the institutional players from that decision-making moment have moved on, what remains are the precedent of having taken action and the knowledge that this action had legal clearance from executive branch lawyers.

This practice is not unique to executive branch decision-making. Scholars have demonstrated that the courts and Congress deploy ambiguous language as a means of avoiding difficult questions or unresolved disputes among their members to reach a consensus to move forward with agreed-upon language. ${ }^{71}$ Treaty negotiators employ "constructive ambiguity" as a means of reaching agreement on controversial details. ${ }^{72}$ In constitutional legal theory, Cass Sunstein terms this phenomenon "incompletely theorized agreements." ${ }^{\prime 3}$ This approach permits judges to agree on an outcome without needing to agree on an underlying legal theory to support that outcome, but Sunstein acknowledges that the practice allows a minority approach to survive the decision. ${ }^{74}$

When the courts, Congress, or treaty negotiators employ ambiguous language, they are, in essence, delegating to another actor discretionary room in which to maneuver. Ambiguity

J. Barron to Attorney General Eric H. Holder, The Withdrawal of OLC CIA Interrogation Opinions (Apr. 15, 2009), available at https://www.justice.gov/sites/default/files/olc/opinions/2009/04/31/withdrawalofficelegal counsel_0.pdf [hereinafter Barron Memorandum].

${ }^{70}$ See Susan Biniaz, Comma but Differentiated Responsibilities: Punctuation and 30 Other Ways Negotiators Have Resolved Issues in the International Climate Change Regime, 6 MICH. J. ENVTL. \& ADMIN. L. (forthcoming 2016).

${ }^{71}$ See, e.g., Lisa Schultz Bressman, Chevron's Mistake, 58 DUKE L.J. 549, 571 (2009); Joseph A. Grundfest \& A. C. Pritchard, Statutes with Multiple Personality Disorders: The Value of Ambiguity in Statutory Design and Interpretation, 54 STAN. L. REV. 627, 640-41 (2002).

72 See Biniaz, supra note 70.

${ }^{73}$ Cass R. Sunstein, Incompletely Theorized Agreements in Constitutional Law, 74 SOC. RES. 1 (2007).

${ }^{74} \mathrm{Id}$. at 15 . 
might permit the parties to get to "yes," but it also provides the president or others with power that may be greater than was intended by any of the parties consenting to that delegation.

Consider how group lawyering operates. Imagine that the president wishes to take an action and that all of the lawyers present (or at least half) believe that he or she can-but for different reasons. Perhaps each of these lawyers who votes to authorize the action holds a different legal theory for why this action should be permitted. No one legal position garners a majority of the group's members. The group authorizes the action despite the lack of consensus on a specific legal theory. If a statement is necessary, the group provides one that either is ambiguous as to the precise legal rationale or provides alternative potential rationales. Multiple options are left on the table to survive another day. The result is that the group avoids taking clear positions to the extent feasible and leaves open its potential legal rationales for as long as possible to allow internal room for debate to continue. ${ }^{75}$ The ambiguity and flexibility in the executive branch's resulting legal position are not necessarily the result of intentional obfuscation, but they might simply represent a genuine disagreement beneath the surface, along with a lack of a decisionmaker or urgent need to resolve it. The group lawyering approach is structurally attuned to keep options on the table for as long as possible and to create "in the alternative" rationales for executive action without necessarily zeroing in on one legal theory.

This process is critically different from asking OLC, or L, for a written legal opinion sanctioning action. Such an opinion might take into account the views of many agencies, but ultimately one person would decide the view of the office. And, perhaps even more importantly, that person would memorialize that theory in an opinion under his or her name, thus claiming accountability for that position.

Group lawyering results in greater ambiguity in the executive's legal rationale, not only in the position that it presents to the public at large, but also within the executive branch itself. In other words, the problem is not the existence of a clear legal rationale that is simply unknown to the public; that clear legal rationale is also unknown inside the executive branch, because it has never been decided.

Why does ambiguity inevitably lead to a ratcheting up of legal authority over time? Once the action is taken and the executive defends its legality, that action serves as precedent for the executive going forward. Ultimately, the executive will be called to defend it, which may require advocating a legal theory that did not originally receive a majority vote; if accepted, that previously marginal legal theory becomes the law of the executive. A committee approach is structurally geared toward providing authority, not toward providing redlines. In our hypothetical above, a majority vote against each proposed legal theory nevertheless results in a vote in favor of executive action, not a vote to cross off each of those minority legal theories. Any one of those theories might thus be the basis for action and remains available to be used in the future by this president or the next. Contrast this result with a judicial opinion in which a judgment fails to receive a majority vote for a particular rationale. Supreme Court jurisprudence has arrived at a complicated solution in which the resulting holding is construed to be that which is considered the "narrowest grounds" for the judgment. ${ }^{76}$ While lower courts might struggle to determine the appropriate holding to follow, they have the Supreme Court's written

75 See Ingber, supra note 35.

${ }^{76}$ Marks v. United States, 430 U.S. 188 (1977). 
opinions and dissents to use as guidance, and they can choose but one rule; that rule will ultimately become entrenched as law, which also incentivizes future judges to seek agreement on their legal rationale. ${ }^{77}$ By contrast, the executive branch lawyering hypothetical that I presented above results in all options remaining on the table.

As to the Obama war powers legacy, when the decision on the table is whether to recalibrate an existing claim of authority, neutral friction and this proclivity toward ambiguity generate a perfect storm in favor of leaving all options on the table. These features have created powerful hurdles to narrowing, for example, the wartime legal architecture for the conflict with $\mathrm{Al} \mathrm{Qaeda,} \mathrm{or,}$ more specifically, the legal standard for detention at Guantánamo, inherited from the Bush administration. That legal standard states that an individual is detainable if he was "part of, or substantially supported, Taliban or al-Qaida forces or associated forces." 78 Per the terms of the government's position in habeas briefs, "part of" and "substantially supported" are each independent grounds for detention. Yet press reporting — and reading between the lines in government briefs_-suggest that significant internal debate arose inside the administration over whether to retain "substantial support" as an independent grounds for detention and, in fact, that sufficient backing did not exist within the executive branch to employ it as forward-looking grounds for detention or targeting. ${ }^{79}$ Nevertheless, there has not been sufficient consensus to actively take it off the table, so administration lawyers have continued to employ the "either/or" language in briefs. ${ }^{80}$ And in keeping that theory on the books - not because it garnered a majority vote but because there was no consensus to reject it - the administration has retained it as part of the law.

Going forward, this legal standard may be important not only for detention but for the executive's targeted killing standard, which draws on the legal theories advanced in habeas litigation. ${ }^{81}$ The Obama administration may have chosen not to employ the support prong now, but it lies there "like a loaded weapon," 82 an explicit government position ready to be employed by a future president.

Hard and Soft Consensus and the Role of Dissent. The rule that a deliberative body employs for decision-making also influences the substantive outcome. The Lawyers Group reportedly operates on a consensus model, which Oona Hathaway describes in a forthcoming piece on the Lawyers Group. ${ }^{83}$ Under her account, the consensus approach stifles dissent and pushes members toward an agreed approach, most typically toward legal approval of a proposed course of action. $^{84}$

That committee lawyering might stifle dissent - even the expression of dissent around the decision-making table - is consistent with social science literature discussing phenomena such as "group think" and the "cascade effect." "Group think" literature indicates that an exclusive

\footnotetext{
${ }^{77}$ For a discussion of the difficulties for courts and an alternative to the Marks approach, see Ryan C. Williams, Questioning Marks: Plurality Decisions and Precedential Constraint, 69 STAN. L. REV. (forthcoming 2016).

78 The word substantially was added under the Obama administration. March 13 Brief, supra note 8, at 2.

${ }^{79}$ Bensayah v. Obama, 610 F.3d 718 (D.C. Cir. 2010) (noting that the government "abandoned" its initial support-based theory and instead argued that Bensayah was "part of" Al Qaeda); Charlie Savage, Obama Team Is Divided on Anti-Terror Tactics, N.Y. TIMES, Mar. 29, 2010, at A1.

${ }^{80}$ Savage, supra note 79 ("So with no consensus, the legal team decided on a tactical approach. For as long as possible they would try to avoid that hard question.").

${ }^{81}$ See Ingber, supra note 7.

${ }^{82}$ Korematsu v. United States, 323 U.S. 214, 246 (1944) (Jackson, J., dissenting).

${ }^{83}$ Hathaway, supra note 51.

${ }^{84} \mathrm{Id}$.
} 
group of decision-makers, particularly if shielded from external influence, might overestimate group unanimity and disregard, or even suppress, individual doubts in the interest of group unity and social tranquility. ${ }^{85}$ Research on the "cascade effect" suggests that individuals may be more likely to go along with a position if they see others taking it. ${ }^{86}$ In the Lawyers Group context, the secrecy surrounding the group's subject matter and proceedings means that group members cannot easily share their concerns or seek additional input from individuals outside of the group, who might be less influenced by the pressures of the group process. ${ }^{87}$ This insider/ outsider status, and the knowledge that the group is expected to operate through consensus, heighten the social pressures to "go along to get along." ${ }^{8}$ A lack of vocalized dissent in the group may, in turn, create a false sense of unanimity, which leads the group members to feel more confident than they perhaps should in the quality of the group's decision. ${ }^{89}$

Reporting on the Lawyers Group suggests, however, that it does not always operate according to what I will call a "hard consensus" approach under which all actors must agree to move forward. Dissenting opinions have not only occurred; they have, at times, been controlling. The process surrounding the Libya intervention, discussed above, is one highly visible example. The standard scholarly narrative has critiqued that legal process as cherry-picking and the result as preordained..$^{90}$ But I see in the Libya case an anomalous event in which the president received a full airing of legal views, and a normally secretive lawyering process resulted in a written, attributed, public account of the executive's legal position, as well as a record of dissent, all of which faced external review and critique. ${ }^{91}$ Whatever one's view on the substantive result, much is to be hailed in that process, which would not have resulted under a "hard consensus" requirement, or a process under which the group produces one unwritten or unsigned conclusion. Unlike those more typical results of the Lawyers Group, we know precisely what the executive's legal position was on Libya; Congress and the public had the opportunity to respond; and future executive actors will have to grapple with the resulting criticism before relying on that position as precedent.

The Libya case suggests that alternatives to the "hard consensus" model exist and may be more permissive of critical decision-making and dissenting opinions. A "soft consensus" approach might be more likely to permit a record of dissent, if not necessarily written dissent. ${ }^{92}$ "Soft consensus" might better permit actors to speak their minds, insulated from the pressure of feeling that they alone stand in the way of the majority, and this approach, in turn, means more views will be aired.

\footnotetext{
85 See IRVING L. JANiS, GROUPTHINK: PSYCHOlOGICAL STUdies OF FOREIGN POLICY DECISIONS AND FIASCOS (1982).

${ }^{86}$ See, e.g., Sushil Bikhchandani, David Hirschleifer \& Ivo Welch, Learning from the Behavior of Others: Conformity, Fads, and Informational Cascades, 12 J. ECON. PERSP. 151 (1998).

${ }^{87}$ See JANIS, supra note 85, at 32.

${ }^{88} \mathrm{Id}$. at $35-47$.

${ }^{89} \mathrm{Id}$. at $37-42$.

${ }^{90}$ Ackerman, supra note 20, at A27.

${ }^{91}$ See, e.g., Dawn Johnsen, Power Wars Symposium: A Study in Contrasting Views of Executive Authority, JUST SECURITY (Nov. 25, 2015), at https://www.justsecurity.org/27891/contrasting-views-executive-authority (noting Libya as a "counterexample[]" to the "occasional excessive secrecy" of other processes).

${ }_{92}$ Many potential means of registering dissent exist, including through leaks to the press. See Pozen, supra note 23 .
} 
Of course, a true "hard consensus" requirement could serve as a greater constraint than a soft model, as long as the question presented is "Can the president act?" and at least one person is willing to hold out. We cannot know whether, for example, had the Libya process played out through the "hard consensus" model, OLC or the Department of Defense would have ultimately stood in the way of continuing to operate in Libya past sixty days. Hathaway's account of the Lawyers Group, particularly when read in light of the social science literature, suggests that powerful forces would have propelled those actors toward "yes." This outcome is particularly so considering that the status quo at that point was continued action; the question on the table was whether to stop, not whether to intervene in the first place. But had one office been inclined to stand in the way, a true "no action without consensus" approach could have restrained the president, even when the "soft consensus" approach clearly did not.

\section{Catalyst-Dependent Legal Process}

A final feature is one about which I have written extensively elsewhere, so I will touch on it here only briefly. It is the catalyst-dependent nature of executive branch decision-making. ${ }^{93}$ Executive officials in the national security realm, including lawyers, are typically called upon to decide only matters that are driven to them by external events. These external triggers, which I call "interpretation catalysts" - the need to file a brief to respond to a lawsuit, or to clear a speech for an executive official—force executive branch lawyers to make decisions through a process that is influenced largely by the particular trigger at hand. These interpretation catalysts affect the process for decision-making, the identity of the players, the drafter, the decider, and the contextual biases, all of which ultimately influence the legal position itself. ${ }^{94}$

For the early years of the Obama administration, many of the legal positions that it had intended to funnel into the slow, deliberative, and forward-looking mechanisms of executive task forces ${ }^{95}$ were immediately sidetracked by the ongoing crush of defensive litigation-lawsuits originally filed against the Bush administration. Briefs had already been filed in these cases, and legal lines had been drawn, and the new administration did not have the luxury of slowly developing its legal positions in a forward-looking deliberative process. Rather, lawyers under Obama generally had to take up these cases right where the prior administration had left off, with perhaps a few weeks' delay for reflection, ${ }^{96}$ and decide whether to continue or alter the administration's legal position in the context of fast-paced litigation where career officials who had been litigating these cases for years held the pen, ran the process, and operated in a culture institutionally built for defense of executive action, which was buffered from political interference by the norms discussed above. ${ }^{97}$

Decision-making in the face of defensive litigation straddles both the neutral friction and power-aggrandizing categories. The prominence of career litigators in this particular catalyst suggests neutral friction; career lawyers and other officials are generally an impediment to change, much to the frustration of incoming political players. But the institutional realities of

93 See Ingber, supra note 32.

${ }^{94} I d$.

95 See, e.g., Exec. Order 13,493, 74 Fed. Reg. 4901 (Jan. 27, 2009).

96 See March 13 Brief, supra note 8.

${ }^{97}$ For a discussion of the myriad legal positions that became entrenched through the course of the Guantánamo litigation, see Curtis A. Bradley \& Jack L. Goldsmith, Obama’s AUMF Legacy, 110 AJIL 628 (2016). 
defensive litigation lean toward guarding executive power and flexibility to the extent possible. Once ratified by the courts - through either affirmative approval or deference-it is nearly impossible to dial back the executive's substantive position on its legal authority. In a context in which the judiciary defers heavily to the executive's positions, this sequence means that the executive's power-protecting litigation position often becomes the entrenched law.

\section{CONCLUSION}

A president who ascends to office on a promise to rectify a predecessor's overly aggressive claims to power faces steep hurdles to reform. And a promise to rein in overreach on both process and substance presents a Catch-22. Forcing substantive legal change means fighting strong forces promoting continuity and protecting executive power. And remediating internal processes can mean entrenching, rather than reforming, wrongheaded or poorly made substantive positions, which themselves may have resulted from abuses of process.

As others have noted, legal process itself is one legacy of the Obama administration. Process may have been, and quite possibly should have been, that administration's priority. But an administration concerned as well with dialing back the executive's substantive legal positions must give some thought ex ante to balancing these goals. The kinds of process reforms that Obama implemented-a move to an inclusive, consensus-based method of legal decisionmaking and a return to a more politically hands-off model of legal guidance-are some of the very features that impede a president's ability to effect substantive change in his administration's legal positions. To critics more concerned with the substantive legal positions that the Obama administration would take, these reforms may have been process overcorrections. In moving immediately to rein in what many had seen as process flaws of the prior administration, his team may have ceded the ability to change some of the prior administration's substantive legal positions.

It is notable that a significant exception to the Obama administration's retention of many of the late Bush-era legal positions is the standard for detainee treatment. Obama reversed course decisively immediately upon entering office, in one of his first executive orders, directing that all detainees be treated humanely, that all interrogations comply with international law and the U.S. Army Field Manual, and that any prior orders to the contrary be revoked. ${ }^{98}$ Reversing the Bush legal position on detainee treatment was a signature priority of the Obama team, and I do not doubt that the team would have, under any circumstances, worked hard to see that goal to fruition. The fact that this decision occurred on the first day of office, however, much like the initial decision to close Guantánamo, places it largely outside the scope and influence of the forces that I discuss in this paper and may provide insight into how other legal decisions might have played out absent those forces.

In considering the long view, I draw a normative distinction between the institutional features that I discuss in this essay. Continuity in legal positions is largely a virtue, not a defect, of the features that constrain decision-making. While neutral friction, which impedes change, may frustrate new decision-makers in the short term, the executive branch is better off in the long term because of its steadying influence.

${ }^{98}$ Exec. Order 13,491, sec. 3(a), 74 Fed. Reg. 4,893 (Jan. 22, 2009); Barron Memorandum, supra note 69 (overturning Bush-era memoranda noncompliant with the executive order). 
My fear, however, is that neutral friction might operate more effectively on presidents inclined toward restraint of executive power. If a correlation exists between an appetite for greater executive power and a willingness to circumvent internal norms in order to assert that power, then the norms of continuity will more forcefully impede presidents inclined to dial back power rather than those inclined toward power aggrandizement.

Moreover, and in contrast to neutral friction, those structural features that favor a ratcheting up in executive claims to power are a dangerous feature of executive decision-making. Ideally, engagement by the other branches would be sufficient pushback against such claims. But many scholars quite reasonably view constraints internal to the executive as the only effective check today on the president's wartime powers in certain areas. I agree that features internal to the executive truly do constrain the president, as I demonstrate here, and that, in certain realms, the courts and Congress tread lightly, if at all. But the discussion in this essay suggests that certain features, in particular those that lead to an inexorable aggrandizement of claims to executive power, require reform. Among these reforms, I suggest that executive action should rest on a single sound legal theory, that dissent should be welcomed and aired, and that, for internal executive branch lawyers to function effectively as real checks on power, in lieu of judicial oversight in some realms, these lawyers must memorialize limits on the president's power.

We will have presidents who make aggressive claims to power. And we will have presidents who try to dial back those claims. All else being equal, that political pendulum swing might itself be a check on the presidency. The self-correcting to and fro might result in an organic equilibrium over time. But presidents do not act in a vacuum. And the internal forces that I discuss here suggest that the pendulum-swing of presidential politics cannot alone balance the state of the president's authority. Instead, without effective external checks on the president, we will see an inevitable, if incremental, one-way ratchet of slowly aggrandizing executive power. 